ORIGINALS (3)

\title{
且具-V 化合物半導体表面へのメタライゼイション*
}

\author{
小川正毅 \\ 日本電気(株)基盤技術研究所 干 213 川䗁市高津区宮崎 4-1-1
}

(1981年 9 月28日受理)

\section{Metallization on III-V Compound Semiconductor Surfaces}

\author{
Masaki OGAWA
}

Basic Technology Research Laboratories, Nippon Electric Co., Ltd., 4-1-1, Miyazaki, Takatsu-ku, Kawasaki 213

(Received September 28, 1981)

\begin{abstract}
Alloying reactions of metal films deposited on chemically etched GaAs and InP surfaces, (Ni/Au-Ge and $\mathrm{Ni}$ films for GaAs, $\mathrm{Au}$ and $\mathrm{Au}-\mathrm{Zn}$ films for $\mathrm{InP}$ ), were studied using micro-probe Auger electron spectroscopy, X-ray photoelectron spectroscopy, reflection and transmission electron diffraction, and $\mathrm{X}$-ray diffraction. The chemically etched surfaces are covered with thin native oxide layers (5-10 $\AA$ thick). Metallization without interfacial native oxide layers is realized by depositing metals, (Ni for GaAs and Au for InP), which have a capability to produce compounds with both III and $\mathrm{V}$ group elements.
\end{abstract}

\section{1. 序}

半導体デバイス上でメタライゼイションとは，一般 に，素子間の配線および電極形成を意味する。素子間の 配線では，金属膜は絶縁膜上に被着されることが多いの に対し，電極形成では，半導体表面上に被着されるとと が多い。本研究で取扱うメタライゼイションとは，後者 の意味でのメタライゼイションである。III-V 化合物半 導体表面へのメタライゼイションは，とくに超高周波デ バイスや光エレクトロニクスデバイスの電極形成上重要 な問題である。ショットキ電極として用いるにせよ, オ 一ミック電極として用いるにせよ，電極特性は金属と半 導体の接触を利用したすのである以上，界面状態に大き く左右される。現実のデバイス製造に用いられる半導体 表面には，でく薄い自然酸化膜が存在している。てのよ うな酸化層が電極界面に残されると, ショットキ障壁高 さの不安定や，接触比抵抗の増大等望ましくない現象を

* 本研究の一部は通商産業省工業技術院の大型プロジ エクト「光応用計測制御システムの研究開発」にも とずいて行われたすのである。
ひきおてす。したがって，良好な電極特性を得るために は, 界面の酸化層を除去する必要がある。このための方 法としては，金属膜の被着前に自然酸化層を除去する か，あるいは，熱処理することにより金属膜と半導体を 合金化させ，界面の自然酸化層を除去する方法が考えら れる。前者の方法として分子線エピタキシー成長法で用 いられている表面清浄化方法, 即ち, イオンエッチング により自然酸化層を除去した後, 加熱してイオンエッチ ングによる結晶のダメージを回復させる方法1)，あるい は, $500^{\circ} \mathrm{C}$ 前後での超高真空中加熱によって自然酸化膜 を除去する方法 ${ }^{2}$ がある。しかしてれらの方法では，加 熱温度が製造プロセス上高すぎたり, 結晶ダメージの回 復が充分でなかったりする欠点3)があり，現実のデバイ ス製造には適用されるに至っていない。金属には，半導 体とよく反応するすのが多く，乙の性質を適切に利用す れば，後者の方法はデバイスプロセスに適用が容易であ るので，現実的な方法といえる。本報告は，III-V 化合 物半導体として代表的な $\mathrm{GaAs}$ および $\mathrm{InP}$ への電極反 応を調べるととによって，合金化に伴う自然酸化層除去 機構の理解を目的としている。 


\section{2. 実 験}

実駼に用いた GaAs, InP は $\mathrm{n}$ 型 (100), (111) A お よび B 面のもので, $\mathrm{GaAs}$ に対しては, $60^{\circ} \mathrm{C}$ の硫酸 • 過酸化水素・水 $(3: 1: 1)$ 混合液で 60 秒エッチン グし, 純水洗浄した後, 窒素ガスでブローし，InP に対

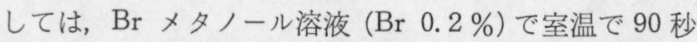
エッチングした後, メタノール洗浄, 純水洗浄, 窒素ガ スブローを行った。これらの試料は, 直ちに真空チェン バーにセットし，イオンポンプで排気し， $1 \times 10^{-7}$ Torr 以下の真空度で金属膜を被着した。GaAs 上に被着した 金属膜は, $\mathrm{Ni} / \mathrm{Au}-\mathrm{Ga}$, 二層膜 ( $\mathrm{Ge} 12$ wt \% の $\mathrm{Au}-\mathrm{Ge}$ を被着した後, $\mathrm{Ni}$ を被着) および $\mathrm{Ni}$ 膜の二種であり, $\mathrm{InP}$ 上に被着した金属膜は $\mathrm{Au}-\mathrm{Zn}$ 膜 (Zn 3 wt. \%) お よび $\mathrm{Au}$ 膜の二種である。 $\mathrm{Ni}$ は電子ビーム蒸着法で被 着し, 他は抵抗加熱法で被着した。被着後, 大気中に取 り出し $200 \sim 500^{\circ} \mathrm{C}$ で水素雾囲気中 (開管) で熱処理し た。エッチング後の結晶表面は XPS (Xray Photoelectron Spectroscopy) で測定し, 熱処理後の電極構造は, 斜め研磨法を用いたマイクロプローブオージュ分析 ${ }^{4}$, X線回折, 反射および透過電子線回折により調べた。

\section{3. 結 果}

\section{1 表面酸化層}

Fig. 1 は, 硫酸・過酸化水素・水 溶液でエッチング した後の GaAs 表面の XPS 結果と, 真空加熱による 変化を示す。試料は純水洗浄・望素ガスブロー後, 直ち

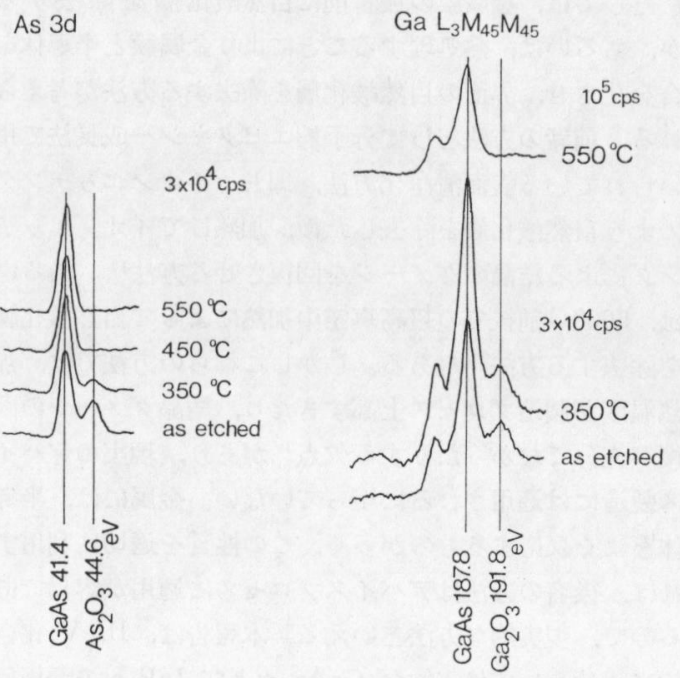

Fig. 1 X-ray photoelectron spectra of chemically etched GaAs substrate and spectral variation under annealing in vacuum.

に XPS 装置 (VG 社 ESCA LAB 5) にセットした。装 置は 3 室構成であるため， 10 分後には $1 \times 10^{-10}$ Torr に到達した。 $\mathrm{MgK}_{\alpha} 15 \mathrm{kV} 20 \mathrm{~mA}$ で励起し, 半球型分 析器で分解能 $0.4 \mathrm{eV}$ の条件で分析器に対し試料面法線 を $60^{\circ}$ 傾むけて測定した。カーボンは $\mathrm{MgK}_{\alpha}$ では $\mathrm{Ga}$ のオージェピークと重なるため, $\mathrm{Al} \mathrm{K}$ 励起して測定 したが、ほとんど検出されなかった。Fig. 1 からエッチ ング後の表面には, $\mathrm{As}_{2} \mathrm{O}_{3}, \mathrm{Ga}_{2} \mathrm{O}_{3}$ からなる酸化層が存 在するととがわかる。(同定には文献5)，6）を参考とし た。）As3d および Ols の平均自由行程をそれぞれ $25 \AA$, $20 \AA^{6)}$ として, 分析器に対する試料の傾きおよび各元 素ピークの感度因子 ${ }^{7)}$ を考慮して計算すると, 酸化層の 厚さは $10 \AA$ と見積られる。 $5 \times 10^{-10}$ Torr 以下の真空 で 30 分間加熱すると, $\mathrm{As}_{2} \mathrm{O}_{3}$ は $350^{\circ} \mathrm{C}$ でかなり減少 し， $450^{\circ} \mathrm{C}$ では完全に消失する。(なお，Fig. 1 では結 合エネルギーはフェルミレベルから測ったすのである。 加熱により各ピークは, 表面電位の変化に応じてシフト するが, Fig. 1 では加熱前の位置に重ねて表示してあ る。）一方, $\mathrm{Ga}_{2} \mathrm{O}_{3}$ は $350^{\circ} \mathrm{C}$ では減少せず, $550^{\circ} \mathrm{C}$ の 加熱で除去された。Fig. 2 は，エッチング後の InP に 対し，Fig. 1 と同様の測定を行ったもので， P 酸化物 は， $350^{\circ} \mathrm{C}$ であ除去されず, $450^{\circ} \mathrm{C}$ で除去された。In は $3 \mathrm{~d}, 4 \mathrm{~d}$ ともに $\mathrm{InP}$ と $\mathrm{In}_{2} \mathrm{O}_{3}$ の化学シフトが少ない ことが報告されている8 。MNN オージェピークでは, $\mathrm{In}_{2} \mathrm{O}_{3}$ で $2.2 \mathrm{eV}$ の化学シフトが報告されているが9 , オ ージェピークはブロードなため, 酸化の程度が少ないと 明膫なスペクトル変化としては現われててない。Fig. 2 で示した MNN オージェスペクトルでは, このような 事情のため, 酸化ピークが分離できていない。GaAs と 同様な方法で見積った酸化層の厚さは $5 \sim 6 \AA$ であっ

P 2p

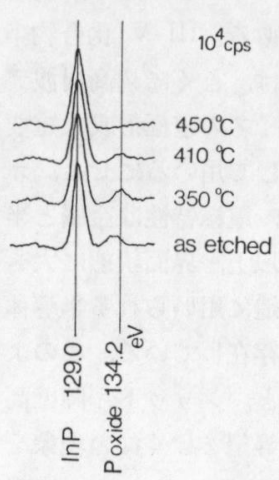

Fig. $2 \mathrm{X}$-ray photoelectron spectra of chemcally etched InP substrate and spectral variation under annealing in vacuum. 
た。図には示していないが, Ols の量は, Fig. 2の P 酸 化物ピーク面積から見積られる量よりかなり多かった。 このことは In 酸化物の存在を示唆しているむのと思わ れる。実際，試料傾角 $0^{\circ}$ と $75^{\circ}$ に対する $\operatorname{In} 4 \mathrm{~d}$ および In LMM スペクトルを比較したととろ, 脱出深さが浅 く表面に敏感な $75^{\circ}$ のスペクトルに $\mathrm{In}_{2} \mathrm{O}_{3}$ の存在を示 唆するスペクトル形状変化が現われており, In 酸化物 が存在することは間違いない。Fig. 2 で， $450^{\circ} \mathrm{C}$ 加熱 で MNN スペクトルが変化しているのは，表面に In が折出したためである10)。

Fig. 1, Fig. 2 で示したように，エッチング後の表面 には, 5〜10 程度の酸化層が存在する。これを真空加 熱法で除去しようとすると, $400^{\circ} \mathrm{C}$ 以上の高温にしなり ればならず，通常のデバイスプロセスへの適用には困難 がある。また単なる真空加熱では，V族元素の飛逸が著 しく，化学量論的に良好な表面が得られない。とくに InP では, 分解温度 $365^{\circ} \mathrm{C}^{11)}$ 以上に加熱するため, In の析出に至ってしまい，V族雾囲気なしには良好な表面 が得られない等, メタライゼイションへの適用には, 困 難な点がある。

\section{$3.2 \mathrm{GaAs}$ 表面へのメタライゼーション}

$\mathrm{GaAs}$ で重要な電極として $\mathrm{Au}-\mathrm{Ge}$ を用いた $\mathrm{n}$ 型 $\mathrm{GaAs}$ へのオーミック電極がある。とくに MESFET

(ショットキ障壁ゲート型電界効果トランジスタ) に適 用する場合には, 低接触抵抗性と同時に, GaAs との均

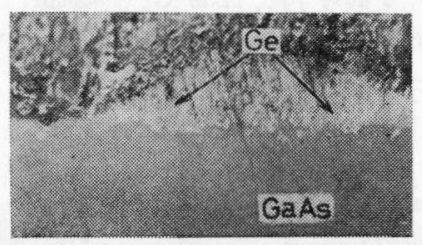

\section{$\mathrm{Au}-\mathrm{Ge} / \mathrm{GaAs}$}

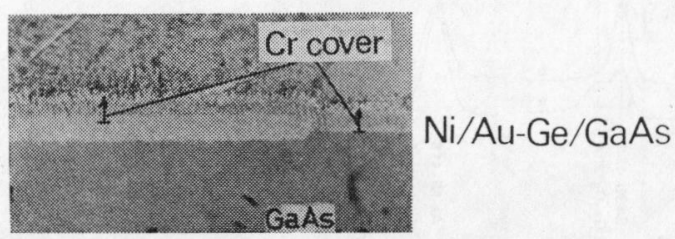

Fig. 3 Bevelled surfaces of $\mathrm{Au}-\mathrm{Ge} / \mathrm{GaAs}$ and $\mathrm{Ni} / \mathrm{Au}-\mathrm{Ge} / \mathrm{GaAs}$ contacts annealed at $500^{\circ} \mathrm{C}$ for 30 seconds. Large $\mathrm{Ge}$ grains are noted in ball-up portion of $\mathrm{Au}-\mathrm{Ge} / \mathrm{GaAs}$. $\mathrm{Cr}$ cover film was deposited after annealing to protect the sample surface from the damage caused during bevelling.
一な合金化，微細形状加工性が要求される。Fig. 3 は $500^{\circ} \mathrm{C}$ で 30 秒間熱処理した $\mathrm{Au}-\mathrm{Ge} / \mathrm{GaAs}$ と Ni/Au$\mathrm{Ge} / \mathrm{GaAs}$ を $2^{\circ}$ で斜め研磨したものの研磨面を示す。 $\mathrm{Au}-\mathrm{Ge}$ のみでは, $\mathrm{Au}-\mathrm{Ge}$ 共晶温度 $\left(356^{\circ} \mathrm{C}\right)$ 以上で, 被着膜は凝集して, いわゆるボールアップ (ball-up) 現 象を示し，局所的にのみ $\mathrm{GaAs}$ と合金化する。またボ ールアップした部分には, 大きな $\mathrm{Ge} の$ 粒子が析出して いる。一方, $\mathrm{Ni}$ 膜で覆ったものではボールアップむな く, GaAs との合金化む均一である。 $\mathrm{Au}-\mathrm{Ge}$ のみでボ

$300^{\circ} \mathrm{C} \quad 30 \mathrm{sec}$
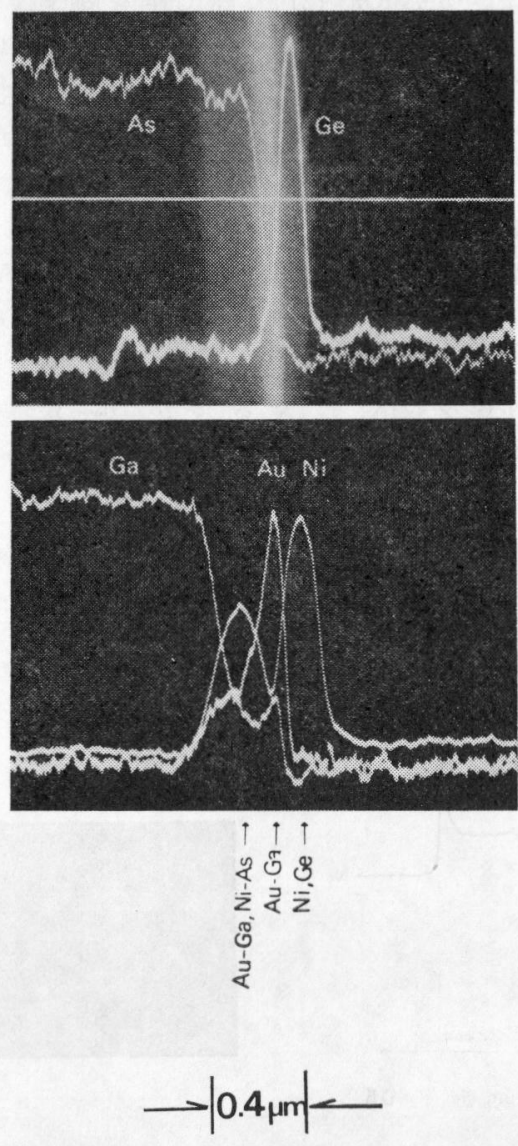

Fig. 4 SEM image and Auger line profile of $\mathrm{Ni} / \mathrm{Au}-\mathrm{Ge} / \mathrm{GaAs}$ sample annealed at $300^{\circ} \mathrm{C}$ for 30 seconds. Auger signal intensities were measured along the scanning line (the horizontal line at the center of the upper figure). The right-hand and left-hand sides of the photographs correspond to the $\mathrm{Cr}$ cover film and the GaAs substrate. The primary probe diameter, the accelerating voltage and the sample current are $0.5 \mu \mathrm{m}, 10 \mathrm{kV}$ and 0.1 $\mu \mathrm{A}$. 
ールアップするのは，Au の GaAs との固相反応性が 低い ${ }^{12}$ ために，昇温時に自然酸化層の薄い部分で $\mathrm{GaAs}$ と局所的にのみ反応し，その反応した部分に融点以上に 加熱されて液体化した $\mathrm{Au}-\mathrm{Ge}$ が凝集するためと説明さ れる ${ }^{13)}$ 。 $\mathrm{Ni}$ で覆った効果を理解するために，200 ${ }^{\circ} \mathrm{C} \sim$ $500^{\circ} \mathrm{C}$ で熱処理した試料を斜め研磨し, マイクロプロー ブオージェによりその構造を分析した。Fig. 4 は, $300^{\circ} \mathrm{C}, 30$ 秒熱処理したもので, $\mathrm{Ni}$ が $\mathrm{GaAs}$ 界面に拡 散し，Ga および As は金属中に拡散しており, 被着膜 との固相反応により $\mathrm{GaAs}$ が分解されているととがわ かる。X 線回折の結果, 多結晶の $\alpha^{\prime}-\mathrm{AuGa}$ (13 at. \% $\mathrm{Ga})$ および $\beta-\mathrm{AuGa}$ (21 at. \% Ga) と同時に, $\mathrm{GaAs}$ 〈111〉に $\mathrm{c}$ 軸を強く配向させた NiAs の形成が認めら れた。GaAs との合金化深さを斜め研磨法で測定したと ころ, 合金化深さは, $300^{\circ} \mathrm{C}, 5$ 分で飽和していた。乙 のととは，Ni/Au-Ge 電極では， $\mathrm{GaAs}$ の分解が，この ような低温でほとんど完了しているととを示している。 $\mathrm{Ni}$ 被覆の効果をさらに理解するために, Ni/GaAs の合 金化反応を調べた。Ni は電子ビーム蒸着法により 0.1 $\mu \mathrm{m}$ の厚さに被着した。オージェ分析から $\mathrm{Ni}$ は $200^{\circ} \mathrm{C}$ から GaAs と反応しはじめることがわかった。Fig. 5 は, $300^{\circ} \mathrm{C}, 5$ 分熱処理したもののオージェプロファイ ルと，その時の反射電子線回折パターンを示す。GaAs との反応性および反応生成物の配向関係の $\mathrm{GaAs}$ 基板面

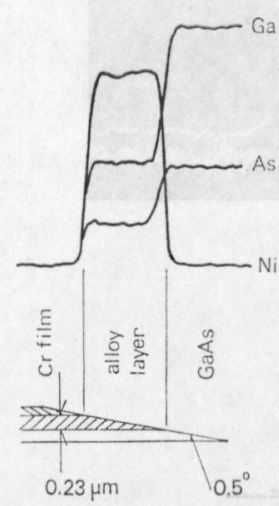

(a)

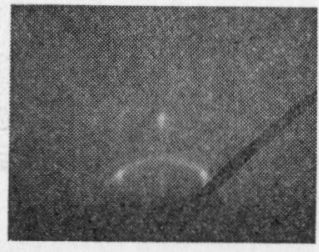

(b)
Fig. 5

(a) Auger depth profileIfor $\mathrm{Ni} / \mathrm{GaAs}$ sample annealed at $300^{\circ} \mathrm{C}$ for $5 \mathrm{~min}$. Auger signal intensities were measuredalong the electron beam scanning line on the bevelled surface.

(b) Reflection electron diffraction pattern taken from the sample annealed at the same conditions as (a). The GaAs substrate is (111) $A$ and the azimuth is $\langle 110\rangle$ for $\mathrm{GaAs}$ and $\langle 112 \overline{0}\rangle$ for the hexagonal reaction product.
方位依存性は認められなかった。Fig. 5 では, 回折パタ ーンの対称性のよい $\mathrm{GaAs}$ (111) A 面を用いている。 電子線は $50 \mathrm{kV}$ 加速で, $\mathrm{GaAs}\langle 110\rangle$ 方位に照射して いる。回折像にはリングパターンとスポットパターンが 重っており，しかすすべてのスポットはリング上にある てとから, 生成物は一部単結晶化していることがわか る。図と同一のパターンは, 陚料を $60^{\circ}$ 回転するたびに 見え，生成物が六方晶系でかつ単結晶化したものは， $\langle 0001\rangle / /\langle 111\rangle \mathrm{GaAs},\langle 11 \overline{2} 0\rangle / /\langle 110\rangle \mathrm{GaAs}$ の関係を持 っているととがわかった。オージェプロファイルは, 反 応層中で均一であり, $\mathrm{Ni}: \mathrm{Ga}: \mathrm{As}=2: 1: 1$ の組成比 に相当したピーク強度比を示した。またりングパターン は格子定数 $a_{0}=3.84 \AA, c_{0}=4.96 \AA$ の六方晶系で指数 づけできた。これらの結果から, $300^{\circ} \mathrm{C} 5$ 分の熱処理で, $\mathrm{Ni}_{2} \mathrm{GaAs}$ の組成を持つ六方晶系の生成物が形成された ということができる。この反応物は $300^{\circ} \mathrm{C} ， 5$ 時間の 熱処理ですべて単結晶化し，かつ超構造を持っていた。 $500^{\circ} \mathrm{C} 5$ 分の熱処理では， $\mathrm{Ni} 2 \mathrm{GaAs}$ は分解し，やはり 六方晶系でかつ $\mathrm{GaAs}$ に対して $\mathrm{Ni}_{2} \mathrm{GaAs}$ と同一の配 向関係をむった $\beta-\mathrm{NiGa} と \mathrm{NiAs}$ の形成が，反射および $200 \mathrm{kV}$ 加速の透過電子線回折で確認された。これらの 生成物の ao ( $\mathrm{Ni}_{2} \mathrm{GaAs} 3.84 \AA$, NiAs 3.61 $\AA, \beta-\mathrm{NiGa}$ 4. $06 \AA$ ) は GaAs (111) 面上の最近接原子間間隔 4.00 $\AA$ と近いため, エピタキシャルに生成したものである。 $\mathrm{Ni}$ との反応に伴う自然酸化膜の挙動を調ぺるために, 膜厚 $10 \AA$ の自然酸化膜を持つ GaAs (100) 面に $120 \AA$ の $\mathrm{Ni}$ を被着し，真空を破らずに， $250^{\circ} \mathrm{C}$ で熱処理し ながら（真空度 $1 \times 10^{-10}$ Torr) $\mathrm{Ni}$ 表面のオージェ分析 を行った。熱処理 10 分後に Ni が $50 \%$ 程度に急減し，

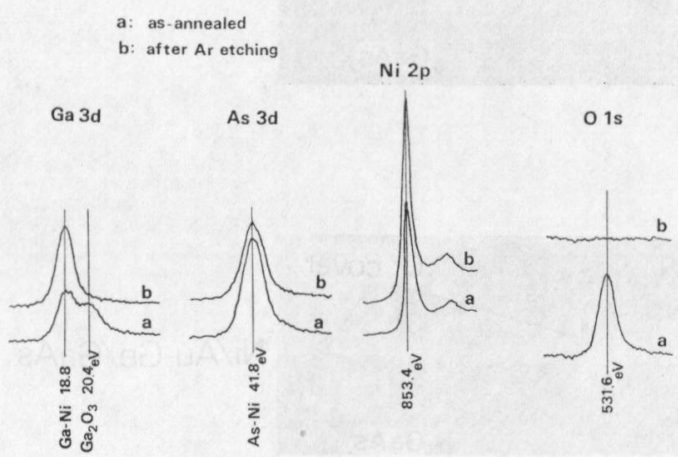

Fig. 6 X-ray photoelectron spectra of $\mathrm{Ni}$ film (120 $\AA$ thick) deposited on chemically etched $\mathrm{GaAs}$ surface in ultrahigh vacuum $\left(1 \times 10^{-10}\right.$ Torr). The sample was annealed in the same vacuum at $250{ }^{\circ} \mathrm{C}$ for $30 \mathrm{~min}$. Spectra were taken from as-annealed surface and $\mathrm{Ar}$ ion etched surface ( $20 \AA$ removed). 
同時に酸素, $\mathrm{Ga}, \mathrm{As}$ が出現した。表面の組成はその後 約 3 分間で一定状態に移行した。Fig. 6 は 30 分間熱処 理した表面, および $0.5 \mathrm{kV}$ 加速のアルゴンイオンで酸 素が消失するまで表面をエッチングした（約 $20 \AA$ 除去） 試料の XPS スペクトルである。熱処理表面では Ga3d, GaLMM に $\mathrm{Ga}_{2} \mathrm{O}_{3}$ ピークが顕著に認められるが，アル ゴンイオンエッチングによって消失する。一方，As3d， Ni 2p はアルゴンエッチングによっても形状の変化がな い。さらにエッチングを行ったが，GaAs 界面には，酸 素は検出されなかった。これらのととは, Ni が自然酸 化膜中を拡散し，GaAs と反応するととにより, 酸化物 と基板側の $\mathrm{As}$ および $\mathrm{Ga}$ との結合を切り, $\mathrm{Ni}$ の侵入 と $\mathrm{Ga}$ および As との化合物形成 $\left(\mathrm{Ni}_{2} \mathrm{GaAs}\right)$ に伴い, 酸化物を表面方向に押しやる機構が支配的に働いている 之解勫できる。 $\mathrm{Ga}$ および As の酸化物は表面に浮かび 上ってくるか゚，蒸気圧の高い As 酸化物は飛散し，Ga 酸化物だけが，表面に残されたのであろう。この解釈を 裏付けるには，しかし，さらに詳細な実験が必要であ る。被着直後の $\mathrm{Ni}$ 表面には, 微量の $\mathrm{As}(\mathrm{GaAs}$ の As 3d 信号の $1 / 20$ ) が認められた。アルゴンエッチングに よって表面を清浄化した $\mathrm{GaAs}$ 上に $\mathrm{Ni}$ を被着した場 合でも, 同程度の As が認められた。との As は, 室 温での $\mathrm{Ni}$ と $\mathrm{GaAs}$ との反応に伴い, 分解されて生成 したものが $\mathrm{Ni}$ 中を拡散して表面に出現したと考えられ る。自然酸化膜の有無にかかわらず, As 量が同程度で あったという事実は，Ni と GaAs の反応では，自然酸 化膜がほとんど妨げとなっていないことを意味している のだと考えられる。

これらの結果から， Ni/Au-Ge 電極での $\mathrm{Ni}$ の役割は 次のように考えられる。即ち, 表面の $\mathrm{Ni}$ は $\mathrm{Au}-\mathrm{Ge}$ 中 を拡散し， $\mathrm{GaAs}$ 酸化層をむ拡散し， $\mathrm{GaAs}$ を低温 $\left(\sim 300^{\circ} \mathrm{C}\right)$ で分解し，界面の自然酸化膜を除去するこ とにより均一な電極反応を進行させる。 $\mathrm{Ni} / \mathrm{AuGe}$ では 分解された $\mathrm{Ga}$ は $\mathrm{Au}$ 之結合して $\mathrm{AuGa}$ を形成し, As が $\mathrm{Ni}$ と結合して $\mathrm{NiAs}$ を形成している。 $\mathrm{Ni}_{2} \mathrm{GaAs}$ を形成するより系全体の自由エネルギーが下がるため， このような反応が進むのだと考えられる。

\subsection{InP 表面へのメタライゼーション}

$\mathrm{Au}-\mathrm{Zn}$ 電極は, $\mathrm{p}$ 型 $\mathrm{InP}$ へのオーミック電極として とくにレーザダイオード等の光エレクトロニクスデバィ スで重要である。この電極でオーミックにするには, $410^{\circ} \mathrm{C} \sim 430^{\circ} \mathrm{C}$ で熱処理する必要がある。Fig. 7 は, $\mathrm{Br}$ ・メタノール溶液でエッチングした $\operatorname{InP}(100)$ 面上 に $0.13 \mu \mathrm{m}$ の Au-Zn 膜 (Zn 3 wt. \% のソースを使 用し抵抗加熱法で蒸着) を被着し， $430^{\circ} \mathrm{C}$ で熱処理した
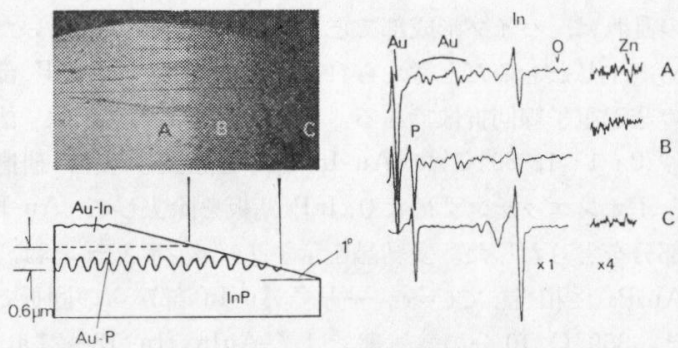

Fig. 7 SEM image and Auger spectra of $\mathrm{Au}-$ $\mathrm{Zn} / \mathrm{InP}$ sample annealed at $430^{\circ} \mathrm{C}$. Auger spectra were measured at the points indicated in SEM image as A, B, and C.

むのの斜め研磨面の SEM 写真と写真上の各点でのオー ジェスペクトルを示す。熱処理は水素雾囲気中で行い, 武料温度か $430^{\circ} \mathrm{C}$ に達した後, 直ちに急冷した。InP との境界は乱れているが， $\mathrm{Au}-\mathrm{Ge} / \mathrm{GaAs}$ のようなボー ルアップはない。 $\mathrm{A}$ 点は $\mathrm{Au}-\mathrm{In}, \mathrm{B}$ 点は $\mathrm{Au}-\mathrm{P}, \mathrm{C}$ 点 は基板の InP である。図からわかるように，熱処理さ 机た電極は, Au-In/Au-P/InP の構造を示している。 被着後の構造としては, $\mathrm{Zn}$ が蒸気圧が高いため先に被 着され $\mathrm{Au} / \mathrm{Zn} / \mathrm{InP}$ を示していたが, $200^{\circ} \mathrm{C}$ 以上で $\mathrm{Au}$ 中に拡散し， $300^{\circ} \mathrm{C}$ 以上では，熱処理雾囲気中に大部 分飛散した。残った $\mathrm{Zn}$ が $410^{\circ} \mathrm{C} \sim 430^{\circ} \mathrm{C}$ で $\mathrm{InP}$ 中 にドープされ $\mathrm{p}^{+}$層を形成するすのと考えられる。高分 解能 SEM による観察を行ったところ, Fig. 7 の $\mathrm{InP}$ 界面での乱れの部分には, 電極表面に向う $\mathrm{Au}-\mathrm{In}$ の細 いパイプが見出された。とれらのととは，Au-P 層か $\mathrm{Au}$ と InP の固相反応のバリア層として働き， $\mathrm{Au}$ と In は Au-P のグレイン境界を拡散するととにより電極 反応が進行するという解釈を支持している。また, 界面

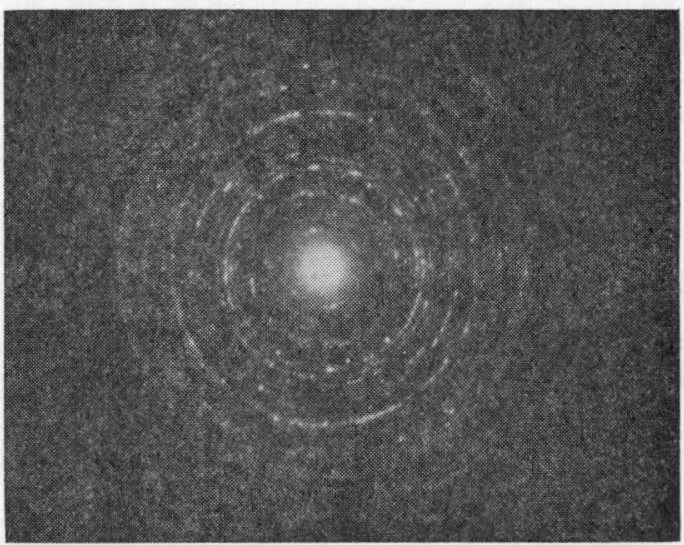

Fig. 8 Transmission electron diffraction pattern of the Au-P rich region. Polycrystalline pattern corresponds to $\mathrm{Au}_{2} \mathrm{P}_{3}$. 
の乱れは，パイプ形成部でとくに $\operatorname{InP}$ の分解が大きいた めに生じたむのだと考えられる。Fig. 8 は， Au-P 部 の透過電子線回折像である。硫酸・過酸化水素・水 溶 液 $\left(3: 1: 1,60^{\circ} \mathrm{C}\right)$ で $\mathrm{Au}-\mathrm{In}$ 部分を除去した後, 研磨 とイオンエッチングにより $\mathrm{InP}$ 基板を除去して $\mathrm{Au}-\mathrm{P}$ 部分をとりだした。多結晶を示すリングパターンは, $\mathrm{Au}_{2} \mathrm{P}_{3}$ に相当している。一方, $\mathrm{Au}-\mathrm{In}$ 部からの回折で は, $350^{\circ} \mathrm{C} 10$ 分の熱処理では $\zeta$-AuIn (In 13〜21 at. \%), $400^{\circ} \mathrm{C} 10$ 分では ら-AuIn と AuIn2 の混在した 構造が観察された。

ここでは示さないが，自然酸化層のないへキ開 $\operatorname{InP}$ 表 面に $\mathrm{Zn}$ を含まない $\mathrm{Au}$ のみを被着した試料に扔いて あ, Fig. 7 と同様の合金化が認められた。このととは, $\mathrm{Au}-\mathrm{Zn} / \mathrm{InP}$ での合金化反応が，本質的に $\mathrm{Au} / \mathrm{InP}$ 之同 一であり，功 $\mathrm{InP}$ 表面の自然酸化層の影響を受けに くいてとを示している*。乙れらの特徵は, 自然酸化層 の影響を強くうける $\mathrm{Au}-\mathrm{Ge} / \mathrm{GaAs}, \mathrm{Au} / \mathrm{GaAs}$ と大きく 異っている。

\section{4. 考 察}

自然酸化膜で覆われた GaAsに対しては，Auは自然 酸化膜に妨げられ，均一な反応を示さない。共晶合金系 のコンタクト $\mathrm{Au}-\mathrm{Ge} / \mathrm{GaAs}$ では, このため, 共晶温度 以上に加熱した時に，液体化した $\mathrm{Au}-\mathrm{Ge}$ が $\mathrm{Au}$ と $\mathrm{GaAs}$ の反応した部分に局部的に凝集するボールアップ 現象を呈してしまう。Au-Ge/GaAs コンタクトを $\mathrm{Ni}$ で覆うとボールアップをおてさず，均一に合金化する。 $\mathrm{Ni}$ は熱処理中に $\mathrm{Au}-\mathrm{Ge}$ 中を拡散し, 固相反応により $\mathrm{GaAs}$ を均一に分解している。 $\mathrm{Ni}$ 亡 GaAs の反応を調 べた結果, $\mathrm{Ni}$ は自然酸化膜の妨げをうけずに $200^{\circ} \mathrm{C}$ か ら GaAs と反応するととがわかった。また, GaAs との 反応に伴って界面の酸化層は除去され，かわって電極表 面に $\mathrm{Ga}_{2} \mathrm{O}_{3}$ が見出された。乙れらのととから自然酸化 膜除去には次のような機構が支配的に働いていると考え られる。すなわち，Ni は自然酸化膜中を昖散し，GaAs と反応するととにより，酸化物と基板の $\mathrm{Ga}$ および As との間の結合を切る。そして, Ni の侵入と $\mathrm{Ga}$ および As との化合物形成に伴い, 酸化物は表面方向に押しや られる。乙の機構が有効であるためには，Ni 原子が自 然酸化膜中を容易に輸送される必要がある。一般に輸送 の大きさは, 拡散係数の大きさと同時に, 濃度勾配によ って決定される。 $\mathrm{Ni}$ は $\mathrm{Ga}$ と As の両者之化合物を形 成するため $\mathrm{GaAs}$ との反応性が高い。すなわち， GaAs

*むちろん自然酸化膜厚が厚い時は，反応は妨げられ る。実際, InP 上の自然酸化膜厚 $20 \AA$ の時は, 一 部に不均一な反応が認められた。
は Ni 原子の吸込み口 (sink) として働く。てのため濃 度勾配が大きくなり， Ni 原子は容易に輸送される。乙 れに対し，Auは $\mathrm{Ga}$ とは化合物を形成するが，As と は形成しないため，As が蒸発等によって取り除かれな いかぎり，GaAs とは強く反応できない。したがって $\mathrm{GaAs}$ は $\mathrm{Au}$ 原子の有効な吸込み口とならないため, $\mathrm{Au}$ 原子は自然酸化膜中を拡散しにくい。一方, InP に 対しては， $\mathrm{Au}$ は In および $\mathrm{P}$ の両者と化合物を形成 するため, InP が $\mathrm{Au}$ 原子の吸込み口となる。したが って, この場合には, 自然酸化膜中を容易に拡散し, 自 然酸化膜に妨げられず反応し，界面に酸化層を残さな い。乙のょうに, III-V 化合物半導体との界面に酸化層 のないメタライゼィションを行うには, III 族および V 族元素の安定な化合物を形成しうる金属を被着するとと が,一つの方法といえる。Pt む $\mathrm{Ni}$ と同様に GaAs と 強い固相反応性を示すが，自然酸化膜の存在する $\mathrm{GaAs}$ 表面では一様な合金化が起りにくく，Pt 中に $1 \%$ 程 度 $\mathrm{Ni}$ を混ぜると一様な合金化が進行するととが知られ ている(4)。乙れは， Ni の強い自然酸化膜除去作用を利 用したものといえるが，同時に，自然酸化膜除去には， III 族と V 族の両者之化合物を形成しうるという性質の みだけではなく，酸化膜を還元しうるという性質む寄与 していることを示しているのかむしれない。すなわち, $\mathrm{Ni}$ は酸素との結合力が大きいため, 界面の自然酸化膜 を一部還元し，自然酸化膜を疎にする結果，Ptが GaAs と反応しやすくなっているのかむしれない。GaAs 自然 酸化膜上の $\mathrm{Ni}$ にてのような還元作用があるかどうかを 調べることは今後の課題である。自然酸化膜の還元反応 は，酸化物生成エネルギーの大きな $\mathrm{Al}$ で顕著なととが 報告されている ${ }^{15)}$ 。しかし， $\mathrm{Al}$ は $\mathrm{Ga}$ との結合力をむ たないので， $\mathrm{GaAs}$ との固相反応がそしく，単に， Ga2 $\mathrm{O}_{3}, \mathrm{As}_{2} \mathrm{O}_{3}$ を還元して $\mathrm{Al}_{2} \mathrm{O}_{3}$ になるだけで, 界面に $\mathrm{Al}_{2} \mathrm{O}_{3}$ からなる酸化層が残ってしまう。したがって, 半 導体との強い固相反応性を持たなりれば, 界面の酸化層 を除去できない。種々の金属が III-V 化合物と固相反応 性をむつかは，III 族および V 族元素との合金の生成 エネルギーがわかれば, 判断がつく。合金の生成エネル ギーの測定值はきわめてそしいが, Miedema ${ }^{16)}$ の半経 験的な值はかなり参考になる。

\section{5. まとめ}

デバイスプロセスに用いる GaAs, InP の表面には, $5 \sim 10 \AA$ 程度の自然酸化膜が存在する。真空加熱に上 り, $\mathrm{GaAs}$ 上の As 酸化物は $350^{\circ} \mathrm{C}$ で減少し, $450^{\circ} \mathrm{C}$ で完全に消失したか， $\mathrm{Ga}$ 酸化物の除去には， $550^{\circ} \mathrm{C}$ の 加熱が必要であった。 InP 上の酸化物は $450^{\circ}$ で除去さ 
れたが, 同時に, In の折出が認められた。自然酸化膜 の存在する $\mathrm{GaAs}$ 上に被着された $\mathrm{Au}$ および $\mathrm{Au}-\mathrm{Ge}$ は自然酸化膜に妨げられ不均一な合金化を示した。 $\mathrm{Ni}$ はこのようなととがなく，均一に合金化し界面に酸化層 を残さない。 $\mathrm{Au}-\mathrm{Ge}$ 上に $\mathrm{Ni}$ を被覆することによっ て, Au-Ge の不均一な合金化は改善される。一方 InP 上では，Au は自然酸化膜に妨げられず合金化する。 $\mathrm{XPS}$, オージェ，X 線および電子線回折による分析の結 果, $\mathrm{GaAs}$ に対する $\mathrm{Ni}$, および $\mathrm{InP}$ に対する $\mathrm{Au}$ の自 然酸化膜除去作用は， $\mathrm{Ni}$ が $\mathrm{Ga}$ および As と化合物を 形成し， $\mathrm{Au}$ が In および $\mathrm{P}$ と化合物を形成するため, それぞれ GaAs および InP に対して高い固相反応性を むつととに起因していると考えられた。

おわりに, 本研究を進めるにあたって, 励ましと助力 を与えて下さった松井純爾, 石田宏一両氏に感謝致しま す。

\section{文献}

1) J. R. Arthur: Surface Science 43 (1974) 449.

2) A. Y. Cho and M. B. Panish: J. Appl. Phys. 43 (1972) 5118.

3) R. C. Blanchet, D. J. Delhomme and J. J. Urgell: presented at 8 th Int. Symp. on GaAs and Related Compounds, Vienne, Autriche, Sept. 22/24 1980.

4）鳥飼俊敬，小川正毅：真空, 23 (1980) 557.

5) P. Pianetta, I. Lindau, C. M. Garner and W. E. Spicer: Phys. Rev. B 18 (1978) 2792.

6) C. R. Brundle and D. Seybold: J. Vac. Sci. Technol. 16 (1979) 1186.

7) 光イオン化断面積 (J. H. Scofield: J. Electron Spectrosc. 8 (1976) 12.) と分析器透過率のエネ ルギー依存性加ら見積った。

8) D. T. Clark, T. Fok, G. G. Roberts and R. W. Sykes: Thin Solid Films 70 (1980) 261.

9) H. Iwasaki, Y. Mizokawa, R. Nishitani and S. Nakamura: Surface Science 86 (1979) 811.

10) R. F. C. Farrow: J. Phys. D: Appl. Phys. 8 (1975) L 87.

11) R. F. C. Farrow: J. Phys. D: Appl. Phys. 7 (1974) 2436.

12) G. Y. Robinson: J. Vac. Sci. Technol. 13(1976) 884.

13) M. Ogawa: J. Appl. Phys. 51 (1980) 406.

14) M. Ogawa, D. Shinoda, N. Kawamura, T. Nozaki and S. Asanabe: Proc. 3 rd Int. Symp. on $\mathrm{GaAs}$ and Related Compounds in Inst. Phys. Conf. Ser. 9 (1971) 268.

15) S. P. Kowalczyk, J. R. Waldrop and R.W. Grant: Appl. Phys. Lett. 38 (1981) 167.

16) A. R. Miedema: Phillips Tech. Rev. 36 (1976) 217. 